\title{
Data report: natural remanent magnetization of IODP Holes U1319A, U1320A, U1322B, and U1324B and magnetic carrier identification by scanning electron microscopy ${ }^{1}$
}

Christine Franke, ${ }^{2,}{ }^{3}$ Yanzhe Fu, ${ }^{3,}{ }^{4}$ David Heslop, ${ }^{3}$ and Tilo von Dobeneck ${ }^{3}$

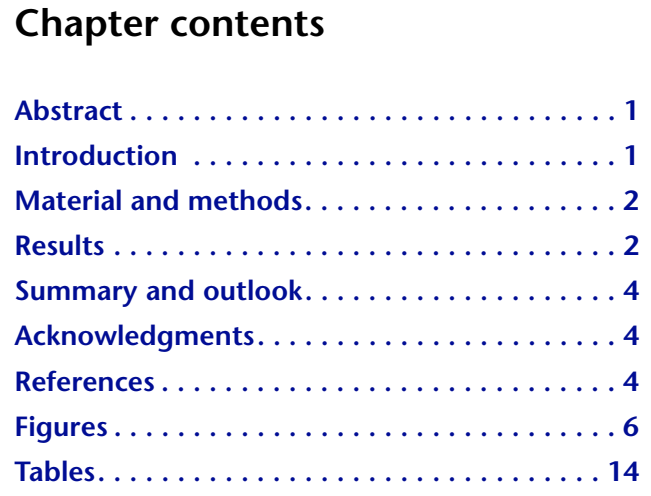

${ }^{1}$ Franke, C., Fu, Y., Heslop, D., and von Dobeneck, T., 2009. Data report: natural remanent magnetization of IODP Holes U1319A, U1320A, U1322B, and U1324B and magnetic carrier identification by scanning electron microscopy. In Flemings, P.B., Behrmann, J.H., John, C.M., and the Expedition 308 Scientists, Proc. IODP, 308: College Station, TX (Integrated Ocean Drilling Program Management International, Inc.). doi:10.2204/iodp.proc.308.209.2009

${ }^{2}$ Laboratoire des Sciences du Climat et de I'Environnement, CEA-CNRS-UVSQ, Campus du CNRS, Bâtiment 12, Avenue de la Terrasse, 91198 Gif-sur-Yvette Cedex, France.

christine.franke@Isce.ipsl.fr

${ }^{3}$ Department of Geosciences, University of Bremen, Klagenfurter Strasse, 28359 Bremen, Germany.

${ }^{4}$ School of Engineering and Sciences, Jacobs University Bremen, Campus Ring 1, 28759

Bremen, Germany.

\begin{abstract}
Paleomagnetic analyses of the natural remanent magnetization of $>1700$ vertically oriented sediment samples from Integrated Ocean Drilling Program (IODP) Holes U1319A, U1320A, U1322B, and U1324B in the northern Gulf of Mexico reveal complex magnetostratographic signals for the Brazos-Trinity and Ursa region carried by detrital iron oxide minerals. Additionally, gyroremanent magnetization was observed to form during alternating-field demagnetization of samples containing an enhanced amount of magnetic iron sulfide minerals. Most characteristic remanent magnetization inclinations are reasonable for the site latitudes. Stable declinations allow for azimuth correction of the formerly unoriented drill cores.
\end{abstract}

\section{Introduction}

During Integrated Ocean Drilling Program (IODP) Expedition 308 in the northern Gulf of Mexico, samples were recovered and subsequently investigated from four drill sites in Brazos-Trinity Basin IV (Holes U1319A and U1320A) and at the continental slope of the Mississippi Fan (Ursa region; Holes U1322B and U1324B) (Fig. F1). Shipboard magnetic measurements on the archive core halves comprised volume-dependent magnetic susceptibility and natural remanent magnetization (NRM), including stepwise alternating-field (AF) demagnetization up to a $30 \mathrm{mT}$ peak field. These two magnetic parameters were correlated to global $\delta^{18} \mathrm{O}$ and magnetic susceptibility stacks and combined with ages derived from micropaleontological analyses to establish a preliminary integrated age model that is described in more detail by the Expedition 308 Scientists (2005). Based on this stratigraphy, the entire drilled sediment successions of the Brazos-Trinity Basin IV appear to be younger than $150 \mathrm{ka}$. Sediments from Ursa Basin are younger and were deposited within the last 60 k.y., during marine isotope Stages (MIS) 1-4. Therefore all four sites have ages that correspond to the normal polarity of the Brunhes Chron (C1n). The NRM signal additionally includes rock magnetic information. Fu et al. (2008) describe the formation of a gyroremanent magnetization (GRM) during AF demagnetization of the sample NRM from Hole U1319A and relate this phenomenon to the presence of diagenetic greigite $\left(\mathrm{Fe}_{3} \mathrm{~S}_{4}\right)$ layers. This information was subsequently employed in the reconstruction of the geochemical and sedimentological environment in Hole U1319A. 
We present here the results of our detailed cryogenic magnetometer analyses including NRM intensity, inclination, and declination records for all four recovered drill sites of Expedition 308. Several directional and rock magnetic corrections explained in the following text were applied to enhance the use of this data set. NRM declination additionally served to reorient the drill cores for further tectonic studies.

\section{Material and methods}

\section{Magnetic techniques}

A total of 1721 oriented cubic samples $\left(6.2 \mathrm{~cm}^{3}\right.$ volume) of wet bulk sediment were collected onboard the $\mathrm{R} / \mathrm{V}$ JOIDES Resolution from the working core halves of all four recovered drill sites at an average spacing of $0.5 \mathrm{~m}$. Holes U1319A, U1320A, and U1322B were sampled throughout the entire recovered depth ranges. The deepest Hole U1324B (612 meters below seafloor [mbsf]) was only sampled to 386 mbsf because consolidation prevented hand sampling at greater depths.

All samples were subject to systematic paleomagnetic analysis comprising stepwise AF demagnetization up to $100 \mathrm{mT}$ peak field using the automated $2 \mathrm{G}$ super-conducting quantum interference device magnetometer at the University of Bremen, Germany. AF steps were increased in $5 \mathrm{mT}$ intervals between 0 and $50 \mathrm{mT}$ and $10 \mathrm{mT}$ intervals between 60 and $100 \mathrm{mT}$. Orthogonal AF demagnetization in $x$-, $y$-, and $z$-directions was followed by measurement of the remaining remanent magnetization.

Samples from Hole U1324B were measured using the method described by Dankers and Zijderveld (1981) where magnetizations are determined after each orthogonal AF demagnetization in order to correct for the acquisition of GRM. This laboratory magnetization is known to form during AF demagnetization in an orientation perpendicular to the direction of the last applied AF (e.g., Dunlop and Özdemir, 1997). Although this measurement technique is three times more time-consuming than the standard routine, it allows the GRM and NRM signals to be separated.

Please note that the sample $x-, y$-, $z$-coordinate system of the University of Bremen magnetometer differs from the $x_{s^{-}}, y_{s^{-}}, z_{s}$-orientation of the JOIDES Resolution shipboard cryogenic magnetometer. This is important for the comparison of shipboard and laboratory data and can be easily reconciled taking the following definitions into account:

$$
x=-y_{\mathrm{s}}, y=x_{\mathrm{s}} \text {, and } z=z_{\mathrm{s}} .
$$

In the IODP standard drilling procedure, one complete drill hole is composed of a certain number of individual drill cores ( $10 \mathrm{~m}$ long). Because each core has a different azimuth orientation relative to the others, the observed NRM declinations were corrected by rotation of the entire cores (e.g., Channell et al., 2008) so that the mean declination is oriented to $0^{\circ}$ as theoretically assumed based on a geocentric axial dipole (GAD) hypothesis for sediments with ages of the Brunhes Chron. Calculated total inclination and declination values for each site are given in Table T1. The mean inclination and declination of all individual drill cores are given in Table T2. In particular, the core-wise declination values may serve as a reorientation tool for other studies because they give the angle for which data from that core has to be rotated with respect to $0^{\circ}$ to obtain the correct geographic orientation.

\section{Scanning electron microscopy techniques}

Samples for electron microscopic analyses of the magnetic carriers were obtained from extracts using a wet magnetic separation technique developed by von Dobeneck et al. (1987). Approximately $10 \mathrm{~mL}$ of sediment was dispersed in demineralized water by ultrasonic agitation using sodium polyphosphate $\left[\mathrm{Na}_{4} \mathrm{P}_{2} \mathrm{O}_{7} \cdot 10 \mathrm{H}_{2} \mathrm{O}\right]$ as a peptizing agent. Magnetic extracts obtained after $48 \mathrm{~h}$ cycling in the extraction apparatus were washed three times with demineralized water to purify the magnetic grains from any remaining clay mineral coatings. Microscopic analyses were performed using a FEI XL30 SFEG scanning electron microscope (SEM) at $15 \mathrm{kV}$ acceleration voltage and $1.5 \mathrm{~nm}$ beam size at the Center of Electron Microscopy Utrecht (EMU) at Utrecht University. A drop of the washed magnetic extract was applied onto a carbon sticker previously stuck on a standard Al stub. After evaporation of the extraction fluid, a thin carbon coating of a few nanometers was applied on the dispersed magnetic particles. Secondary electron and backscattered electron (BSE) imaging techniques were used for visualizations and energy dispersive X-ray spectroscopy (EDS) was performed to examine the elemental composition (Goldstein et al., 1981). The EDAX PhiRhoZ processing software was utilized to (semi)quantify the obtained elemental spectra.

\section{Results}

\section{Paleomagnetic analysis of Brazos-Trinity Basin IV (Holes U1319A and U1320A)}

Individual sample AF demagnetization curves can be divided into three general direction intervals (Figs. F2 and F3): 
1. Low-field steps $(0-30 \mathrm{mT})$ show an overprint due to the presence of a near vertical drillinginduced remanence (DIRM),

2. Intermediate-field steps $(30-60 \mathrm{mT})$ represent characteristic remanent magnetization (ChRM) directions and point toward the origin of the coordinate system.

3. High-field steps ( $60-100 \mathrm{mT})$ can develop a strong horizontal deviation (see also Fu et al., 2008). Typically after the $60 \mathrm{mT}$ AF demagnetization treatment, a strong increase of overall remanence attributed to gyroremanence can be observed in numerous samples. According to $\mathrm{Fu}$ et al. (2008), these depth intervals have a mixed magnetomineralogy of (titano)magnetite and greigite or even a dominant greigite composition.

Figure F4A compares NRM intensities of Hole U1319A for the $0 \mathrm{mT}$ (light gray curve) and $30 \mathrm{mT}$ steps (dark gray curve). It becomes clear that the 0 $\mathrm{mT}$ step (which is actually equivalent to the original NRM before any demagnetization) includes a relatively large contribution from DIRM, which was removed from the signal after the $30 \mathrm{mT}$ treatment. Figure F4B shows the inclination record of Hole U1319A. Values (Table T1) average $\sim 45^{\circ}$, an expected inclination for this latitude $\left(27^{\circ} 16^{\prime} \mathrm{N}\right)$ and time interval. The inclination signal appears to be much noisier below $\sim 60$ mbsf, coinciding with the change from advanced piston coring to the extended core barrel drilling technique. This effect can also be seen in the azimuth-corrected ChRM declination signal (Fig. F4C) which averages, $\sim 0^{\circ}$, as expected. Nevertheless, because of the higher noise level in particular below $100 \mathrm{mbsf}$, the mean declination value $D_{\text {tot }}=345.9^{\circ}$ (Table T1) deviates $\sim 14^{\circ}$ from the expected GAD value. To test the influence of the drilling disturbance on the error in declination we calculated the mean value for the obviously less disturbed sediment section between 0 and 100 mbsf and the section below separately. This results in a mean declination at Site U1319 of $1.9^{\circ}$ for the upper and $346.2^{\circ}\left(-13.8^{\circ}\right)$ for the lower drill section. We can therefore conclude that the lower drill cores are heavily disturbed, whereas for the upper drill section the deviation from the theoretical assumed declination is $<2^{\circ}$.

The NRM intensity signal of Hole U1320A (Fig. F5A) is patchy and incomplete because of the relatively poor core recovery in certain depth horizons. But a correlation of Hole U1320A to U1319A is still possible via a combination of the stratigraphic core description and the magnetic susceptibility and NRM intensity records as already outlined in the "Methods" chapter. Inclinations (Fig. F5B) and declina- tions (Fig. F5C) in Hole U1320A generally show nearly the same average values (Table T1) as in Hole U1319A but exhibit locally higher noise levels, which particularly affect the declination record between 120 and 165 mbsf as well as between 185 and 230 mbsf.

\section{Paleomagnetic analysis of the Ursa Basin (Holes U1322B and U1324B)}

NRM intensity records of Holes U1322B and U1324B (Figs. F6A, F7A) correlate reasonably well with each other up to the lithologic depth horizon marked by seismic layer S30 (defined in Expedition 308 Scientists, 2005). The values are rather low within the first lithologic layer (between the seafloor and seismic reflector S10). Below this depth, NRM intensity values are much higher for both Ursa sites and also show a higher signal variance comparable to NRM intensities for Brazos-Trinity sites. In contrast, the Ursa sites comprise generally tenfold higher NRM intensities than the Brazos-Trinity sites.

The directional information for Holes U1322B and $\mathrm{U} 1324 \mathrm{~B}$ is more varied than for the Brazos-Trinity drill sites presumably because of the complicated levee-channel paleosedimentation system and the postdepositional tectonics (cf. "Expedition 308 summary" chapter and Fig. F33 therein) as well as to higher drilling disturbances (Expedition 308 Scientists, 2005). When using the same declination correction technique as described above, the data still yield reasonable results (Table T1) for Hole U1324B and for most sections of Hole U1322B. For the latter site, the interval between $\sim 20$ and 120 mbsf seems to be more disturbed than the rest of the sedimentary succession and therefore causes a much larger deviation from $0^{\circ}$ than observed at Site U1324. Unfortunately the drilling disturbance for Site U1322 seems to be too important to be able to correct sufficiently for this azimuth disorientation. Nevertheless, the NRM intensity signals between both Ursa sites seem to correlate reasonably well so that comparison between both signals is still possible since Hole U1324B may be used as a reference site for Hole U1322B. The inclination of Hole U1322B (latitude $28^{\circ} 06^{\prime} \mathrm{N}$ ) is on average lower than expected with values $\sim 32^{\circ}$, whereas the inclination of Hole U1324B (latitude $28^{\circ} 05^{\prime} \mathrm{N}$ ) averages $\sim 68^{\circ}$, much steeper than expected for this region.

\section{SEM analyses of the magnetic mineral assemblage (Hole U1319A)}

SEM analyses were performed on dispersed samples of magnetic extracts from core catcher Samples 308- 
U1319A-2H-CC (14.4 mbsf) and 3H-CC (23.8 mbsf) of Hole U1319A. Micrographs (Fig. F8) and element spectra (Table T3) show detrital magnetite (particles 7, 10, 14, 15, and 18 in Fig. F8 and Table T3), titanomagnetite (particles 4, 8, 9, 14, and 17 in Fig. F8 and Table T3), and Ti-rich hemoilmenite (particles 5 and 6 in Fig. F8 and Table T3) within a $0.1-10 \mu \mathrm{m}$ grain size range. The presumably terrigenous magnetite grains have irregular fragmental or anhedral shapes and weathered, slightly knobby surfaces (e.g., Freeman, 1986). Detrital titanomagnetites exhibit a fragmented appearance with smooth conchoidal surfaces and sharp curved edges related to shrinkage cracks (Petersen and Vali, 1987). The (semi)quantitative EDS spectra typically show lower Fe:Ti ratios for hemoilmenites than for titanomagnetites; these mineral phases of the magnetite-ulvöspinel solid solution series can be identified by the intensity of the characteristic $\mathrm{Fe}-\mathrm{K} \alpha$ and $\mathrm{Ti}-\mathrm{K} \alpha$ lines as reported by Dillon and Franke (2009). Some Fe oxides show signs of reductive dissolution or even mixed oxide/sulfide elemental compositions (e.g., particle 16 in Fig. F8 and Table T3). Clusters of fine-grained Fe sulfides were observed next to much coarser FeTi oxides. Their respective element spectra identify these mineral phases as pyrite $\left(\mathrm{FeS}_{2}\right)$ and greigite $\left(\mathrm{Fe}_{3} \mathrm{~S}_{4}\right)$. Greigite occurs in homogeneous clusters composed of particles a few nanometers in size (particles 1-3, 11, and 13 in Fig. F8 and Table T3), whereas clusters of pyrite particles (e.g., particle 12 in Fig. F8 and Table T3) generally consist of larger grains with varying sizes ( $1 \mu \mathrm{m}$ down to a few hundred nanometers). The observed pyrite crystals have typical octahedral shapes and show a brighter contrast in BSE micrographs.

\section{Summary and outlook}

The results of the SEM analyses are consistent with the NRM measurements, showing a complex signal carried by an alternating succession of primary input of iron oxides and presumably secondary precipitated iron sulfides. Detrital magnetite, titanomagnetite, and hemoilmenite grains were detected adjacent to finer clusters of greigite and pyrite. Therefore it has to be kept in mind that the NRM intensity mainly reflects the rock magnetic variations for the investigated four drill sites from Expedition 308. This suggests that standard paleomagnetic interpretations of secular variation and relative paleointensity may not apply straightforwardly in this case.

Nevertheless, the paleomagnetic directional information could be extracted using a careful azimuth correction technique that was used to assist the reorientation of the drill cores required, for example, for further sediment tectonic studies. In general, this reorientation approach seems to work reasonably well (with disorientation of only a few degrees), although in places the inclination and declination records are very noisy because of drilling-induced disturbances.

Additional work has to be performed to obtain a better understanding of the complex depositional and postdepositional processes, such as the distinction of the primary detrital input and its secondary geochemical alteration. The presence of authigenic greigite was shown in more detail for Hole U1319A by Fu et al. (2008) and can be assumed for all four investigated drill sites. This complicates a straightforward interpretation of the recovered remanence signals and requires further rock magnetic measurements and geochemical modeling but also suggests a high potential for paleoenvironmental (magnetic) implications.

\section{Acknowledgments}

The samples for this study were provided by the Integrated Ocean Drilling Program (IODP). The authors would like to thank all IODP Expedition 308 Scientists and technical staff for their shipboard assistance and support. We are grateful for the constructive reviews of the manuscript by P.B. Flemings and an anonymous reviewer. Shore-based magnetic studies were performed at the Department of Geosciences at the University of Bremen, Germany. In particular we would like to acknowledge T. Frederichs for his support with the cryogenic magnetometer measurements. The electron microscopic analyses were performed at the EMU at Utrecht University, the Netherlands. The project was funded through IODP Germany by the German Research Foundation (DFG), grant number DO 705/2-1.

\section{References}

Channell, J.E.T., Hodell, D.A., Xuan, C., Mazaud, A., and Stoner, J.S., 2008. Age calibrated relative paleointensity for the last 1.5 Myr at IODP Site U1308 (North Atlantic). Earth Planet Sci. Lett., 274(1-2):59-71. doi:10.1016/ j.epsl.2008.07.005

Dankers, P.H.M., and Zijderveld, J.D.A., 1981. Alternating field demagnetization of rocks, and the problem of gyromagnetic remanence. Earth Planet. Sci. Lett., 53(1):89-92. doi:10.1016/0012-821X(81)90029-7

Dillon, M., and Franke, C., 2009. Diagenetic alteration of natural Fe-Ti oxides identified by energy dispersive spectroscopy and low-temperature magnetic remanence and hysteresis measurements. Phys. Earth Planet. Inter., 172(3-4):141-156. doi:10.1016/j.pepi.2008.08.003 
Dunlop, D.J., and Özdemir, Ö., 1997. Rock Magnetism: Fundamentals and Frontiers: Cambridge (Cambridge Univ. Press).

Expedition 308 Scientists, 2005. Overpressure and fluid flow processes in the deepwater Gulf of Mexico: slope stability, seeps, and shallow-water flow. IODP Prel. Rept., 308. doi:10.2204/iodp.pr.308.2005

Freeman, R., 1986. Magnetic mineralogy of pelagic limestones. Geophys. J. R. Astron. Soc., 85:433-452.

Fu, Y., von Dobeneck, T., Franke, C., Heslop, D., and Kasten, S., 2008. Rock magnetic identification and geochemical process models of greigite formation in Quaternary marine sediments from the Gulf of Mexico (IODP Hole U1319A). Earth Planet. Sci. Lett., 275(34):233-245. doi:10.1016/j.epsl.2008.07.034
Goldstein, J.I., Newbury, D.E., Echlin, P., Joyce, D.C., Fiori, C., and Lifshin, E., 1981. Scanning Electron Microscopy and X-ray Microanalysis: New York (Plenum).

Petersen, N., and Vali, H., 1987. Observation of shrinkage cracks in ocean floor titanomagnetites. Phys. Earth Planet. Inter., 46(1-3):197-205. doi:10.1016/00319201(87)90182-8

von Dobeneck, T., Petersen, N., and Vali, H., 1987. Bakterielle magnetofossilien-paläomagnetische und paläontologische spuren einer ungewöhnlichen bakteriengruppe. Geowiss. Unserer Zeit, 5:27-35.

Initial receipt: 7 April 2008

Acceptance: 9 October 2008

Publication: 6 April 2009

MS 308-209 
Figure F1. Map of the Gulf of Mexico, showing drilling positions of IODP Sites U1319 (1430 mbsl) and U1320 (1470 mbsl) in Brazos-Trinity region and Sites U1322 (1319 msbl) and U1324 (1057 mbsl) in Ursa region. Black lines $=$ off shore water depth isobaths of 500, 1000, and $2000 \mathrm{mbsl}$.

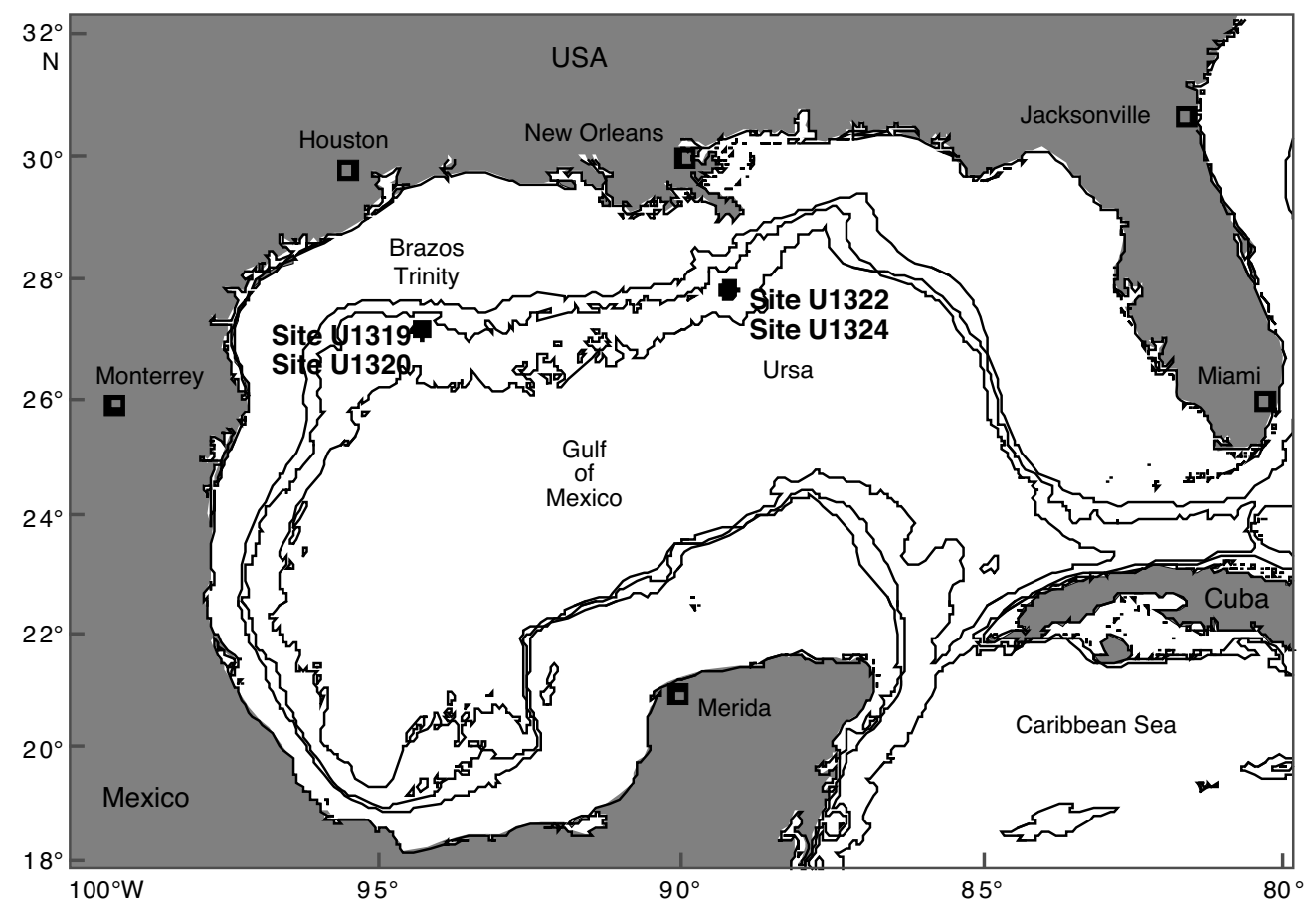


Figure F2. Representative orthogonal vector plots of AF demagnetization steps, Sites U1319 and U1320. A. Type 1 curve, Hole U1319A ( 8.26 mbsf). B. Type 2 curve, Hole U1319A (16.26 mbsf). C. Type 1 curve, Hole U1320A (163.96 mbsf). D. Type 2 curve, Hole U1319A (188.86 mbsf). Type 1 curves show directional deviation during the first few low-field steps, which usually disappears after the $30 \mathrm{mT}$ step, followed by characteristic remanent magnetization (ChRM) directions pointing toward the coordinate center. Type 2 curves show the same starting trend but additionally develop a strong horizontal deviation at higher demagnetization steps. DIRM = drillinginduced remanent magnetization, GRM = gyroremanent magnetization.
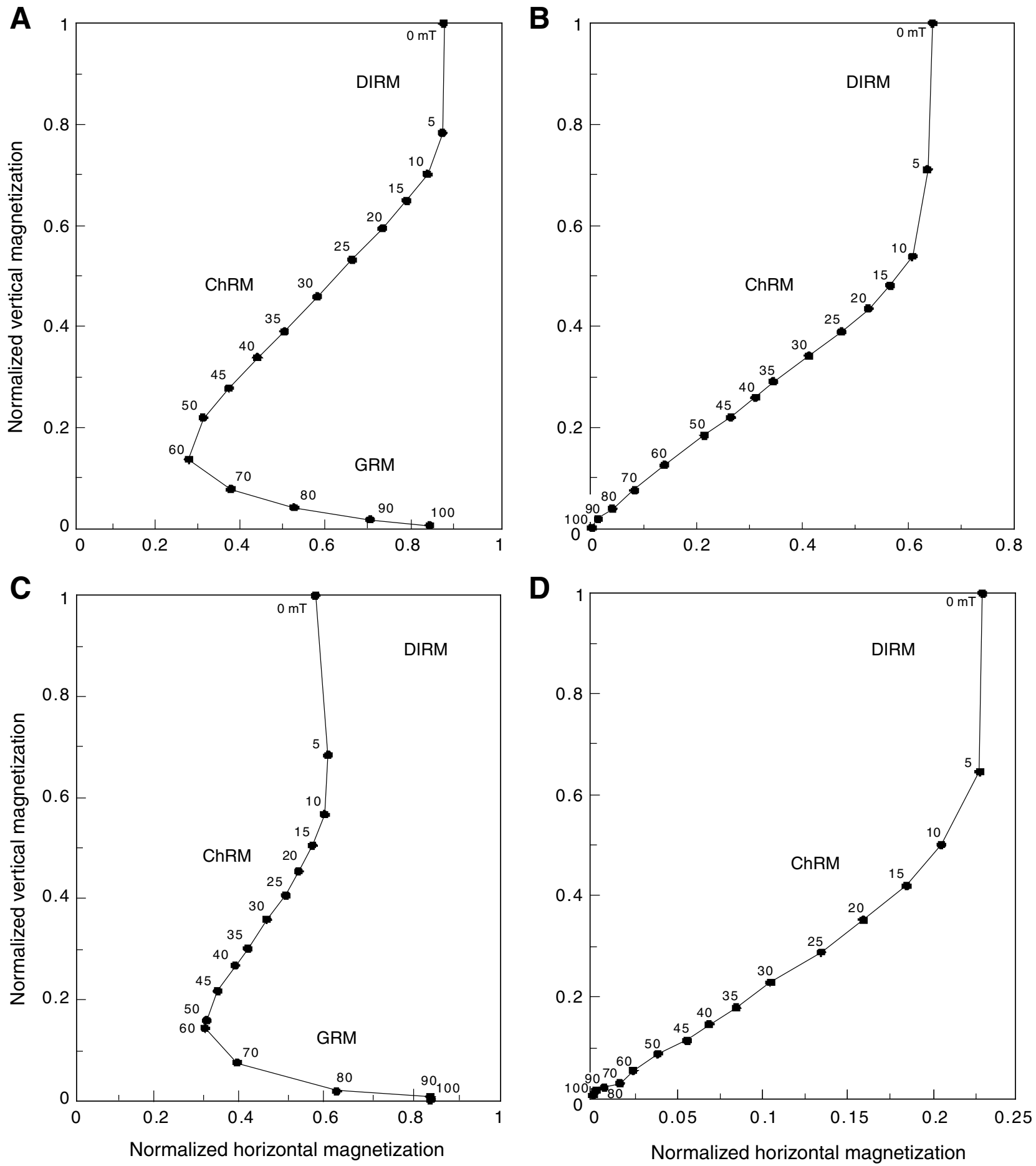
Figure F3. Representative orthogonal vector plots of AF demagnetization steps, Sites U1322 and U1324. A. Type 1 curve, Hole U1322B (25.26 mbsf). B. Type 2 curve, Hole U1322B ( $96.36 \mathrm{mbsf})$. C. Type 1 curve, Hole U1324B (11.56 mbsf). D. Type 2 curve, Hole U1324B (12.06 mbsf). Type 1 curves show directional deviation during the first few low-field steps, which usually disappears after the $30 \mathrm{mT}$ step, followed by characteristic remanent magnetization (ChRM) directions pointing toward the coordinate center. Type 2 curves show the same starting trend but additionally develop a strong horizontal deviation at higher demagnetization steps. Gray line $=$ gyroremanent magnetization (GRM)-corrected demagnetization curve measured following method described by Dankers and Zijderveld (1981), for further details see the text. DIRM = drilling-induced remanent magnetization.
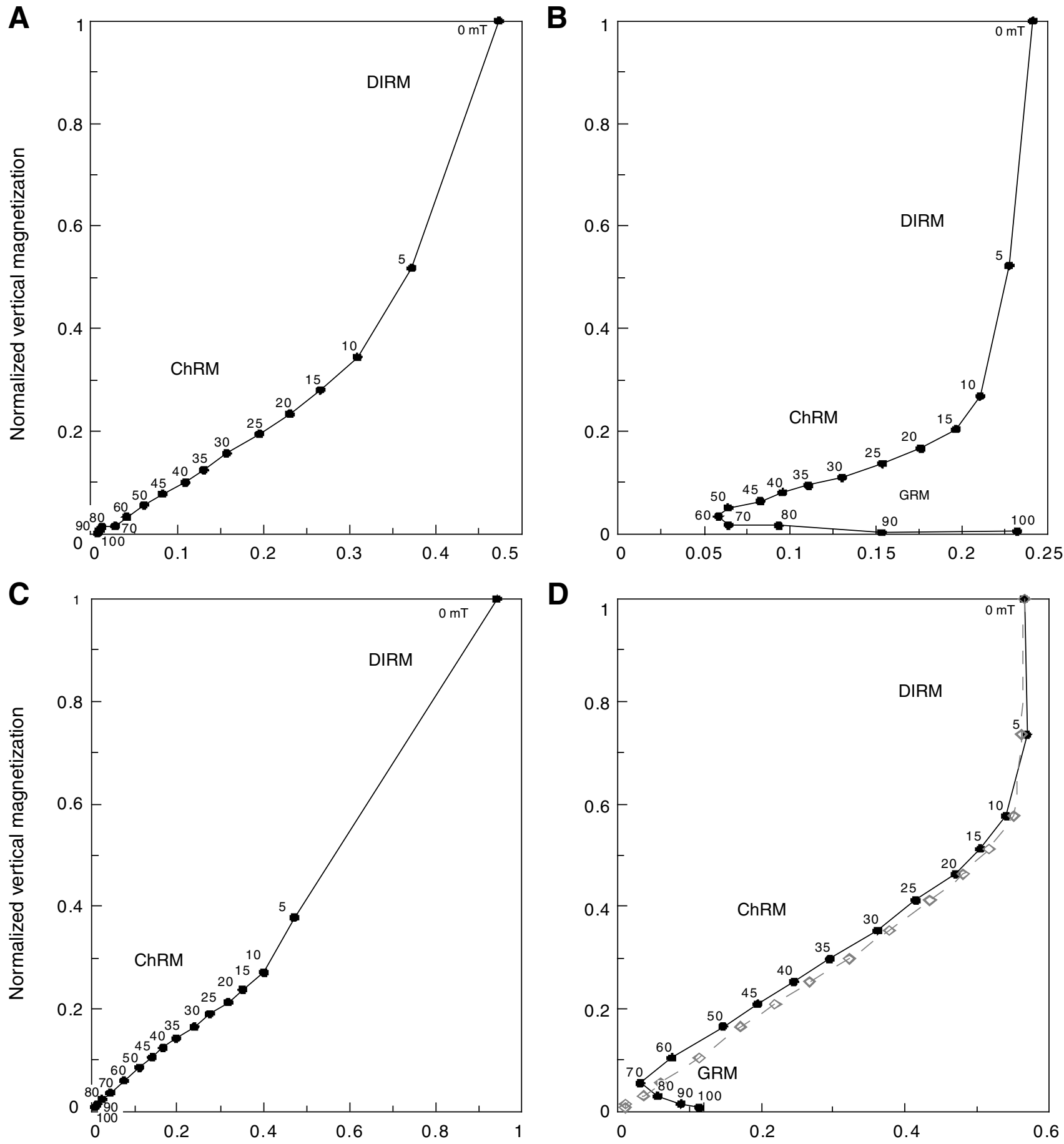

Normalized horizontal magnetization

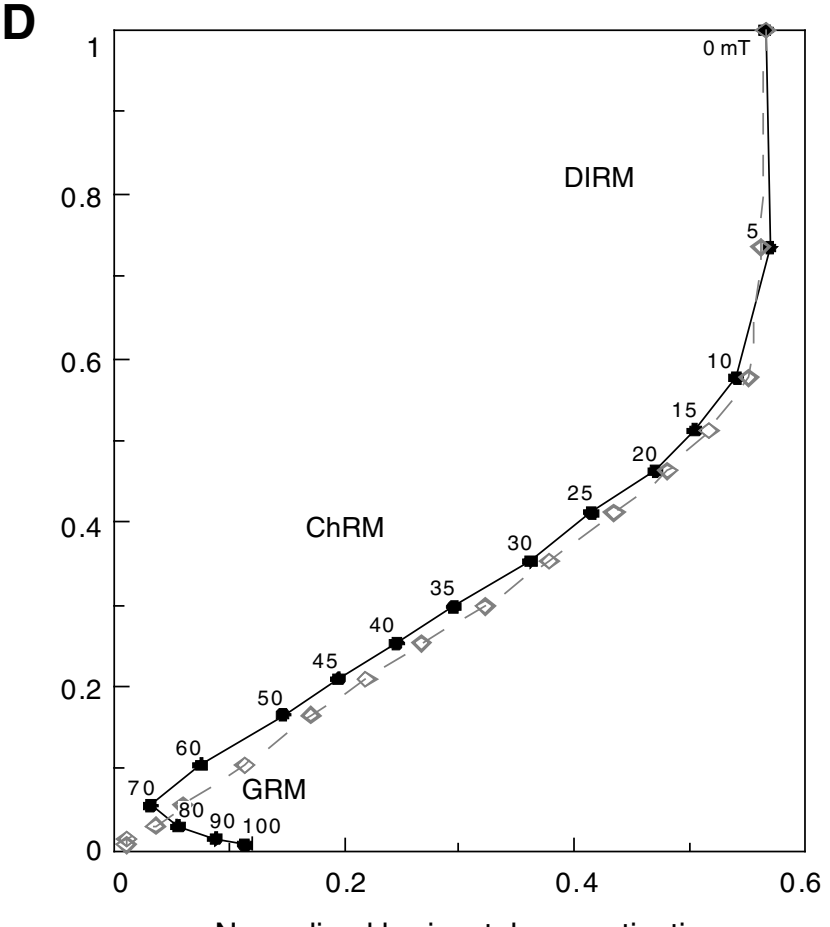

Normalized horizontal magnetization 
Figure F4. Hole U1319A (A) natural remanent magnetization (NRM) intensity for $0 \mathrm{mT}$ (light gray) and $30 \mathrm{mT}$ (dark gray) AF demagnetization steps, ChRM (B) inclination and (C) declination.

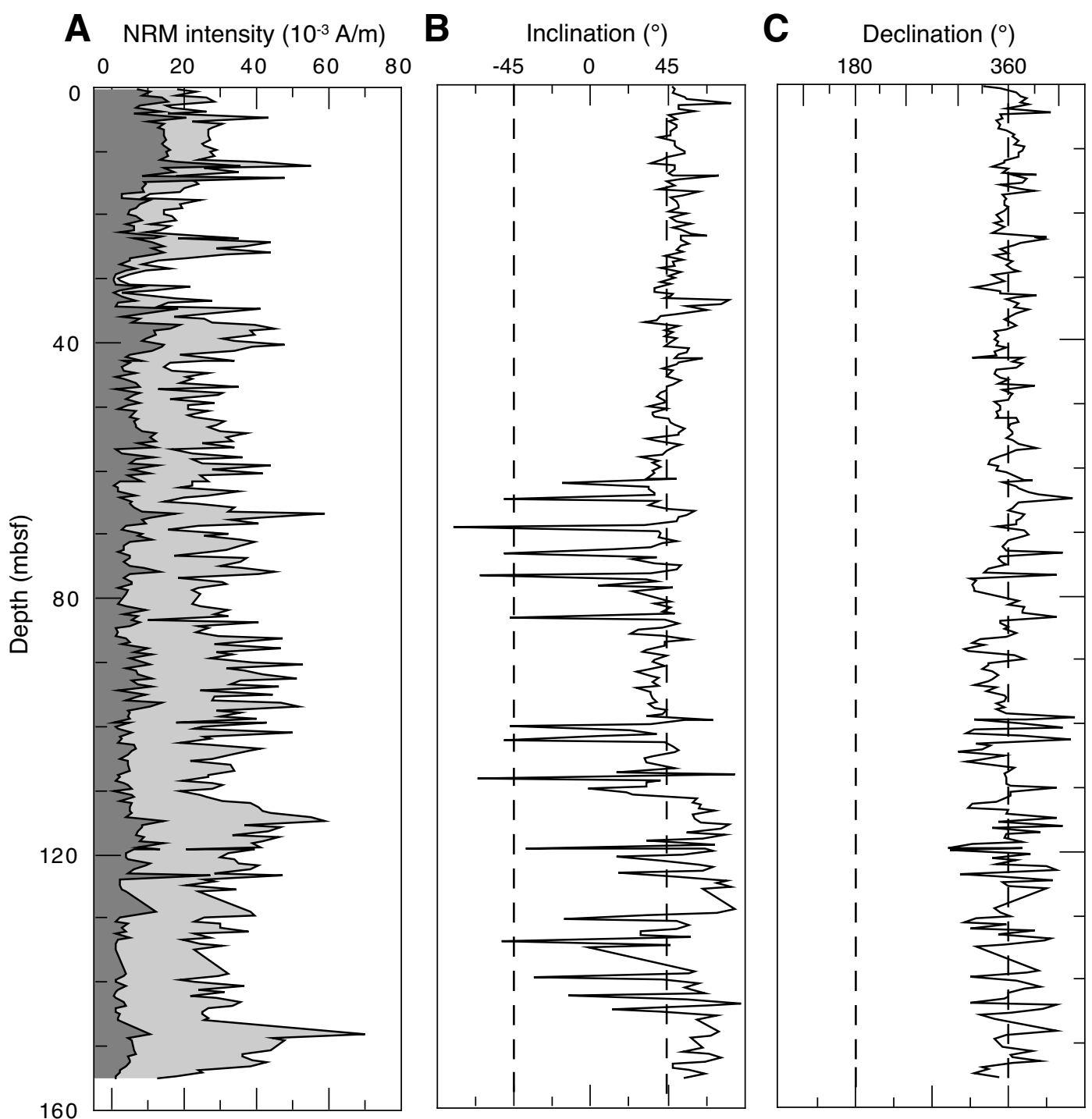


Figure F5. Hole U1320A (A) natural remanent magnetization (NRM) intensity for $0 \mathrm{mT}$ (light gray) and $30 \mathrm{mT}$ (dark gray) AF demagnetization steps, ChRM (B) inclination and (C) declination. Gray hatched areas = intervals of insufficient core recovery for analysis.

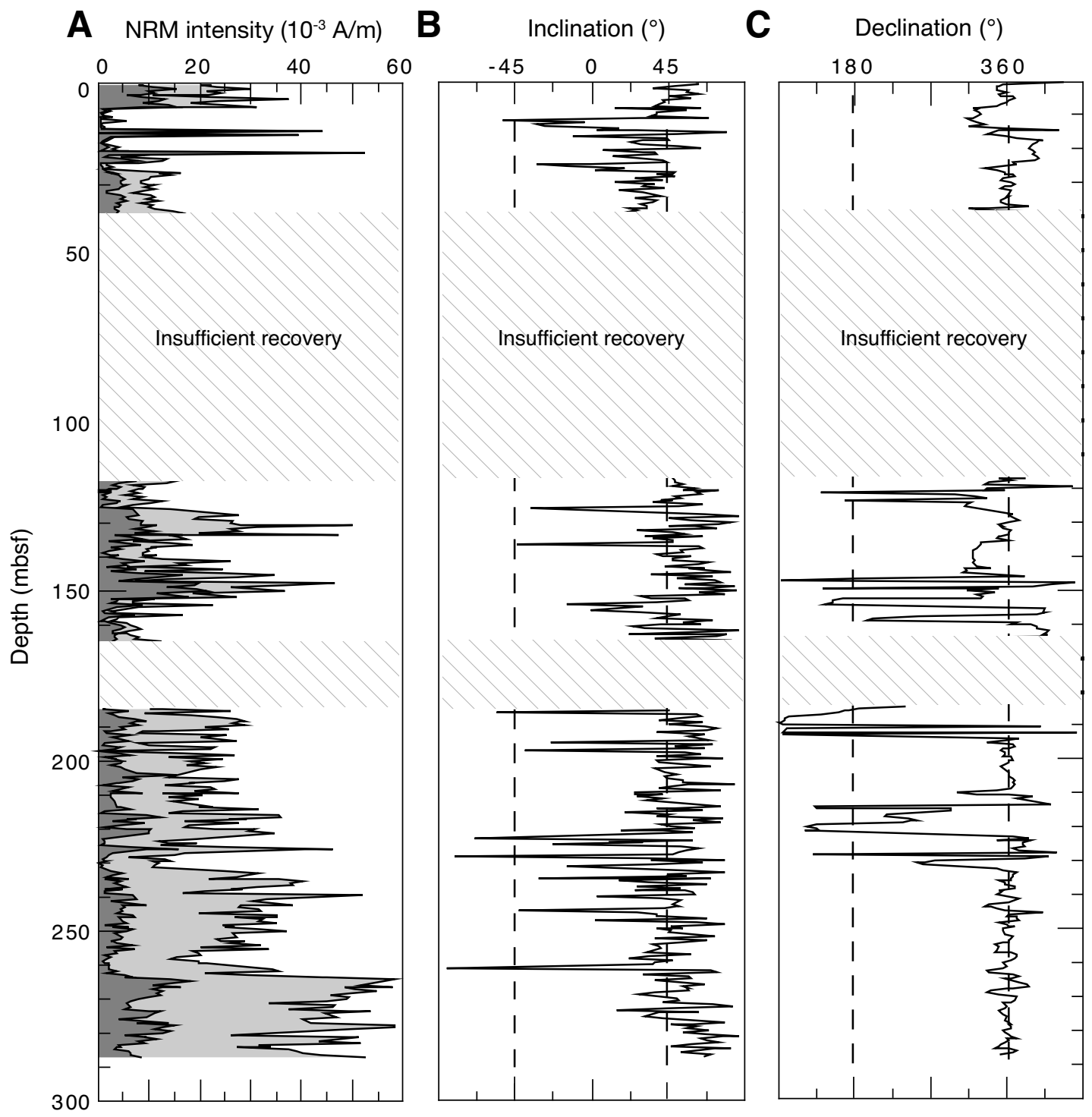


Figure F6. Hole U1322B (A) natural remanent magnetization (NRM) intensity for $0 \mathrm{mT}$ (light gray) and $30 \mathrm{mT}$ (dark gray) AF demagnetization steps, ChRM (B) inclination and (C) declination.

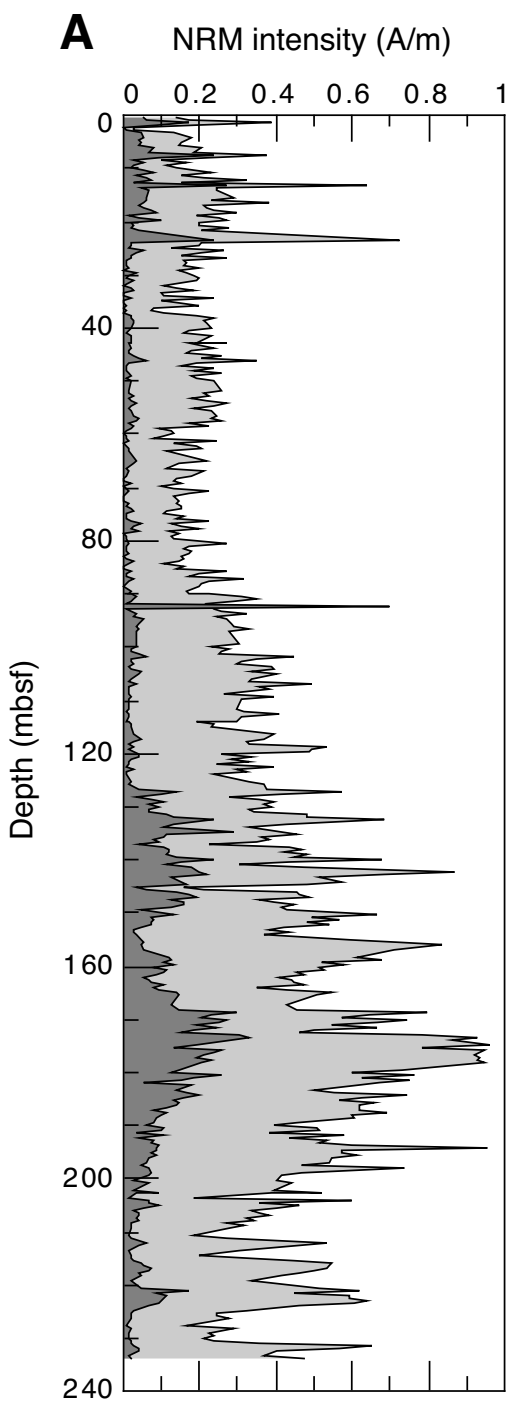

B Inclination $\left({ }^{\circ}\right)$

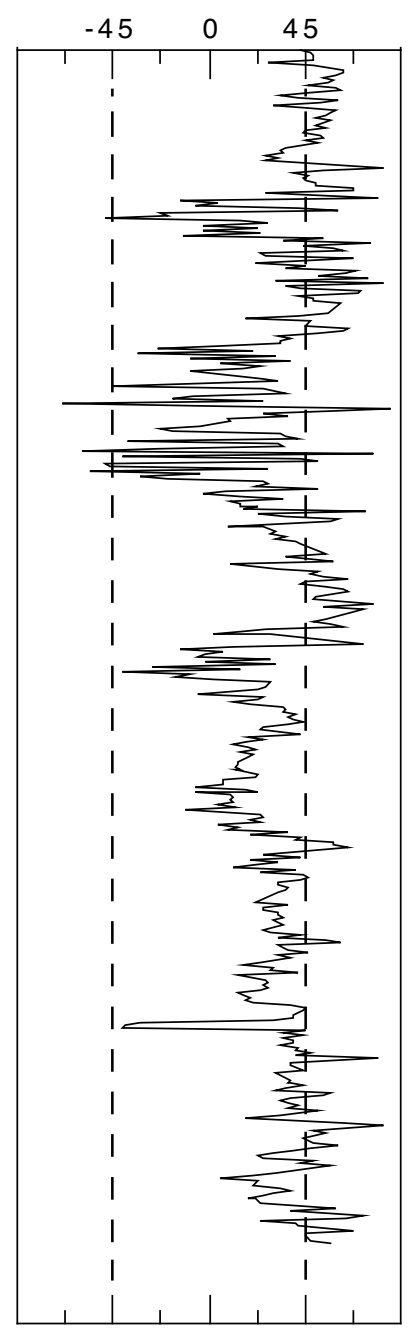

C Declination $\left({ }^{\circ}\right)$

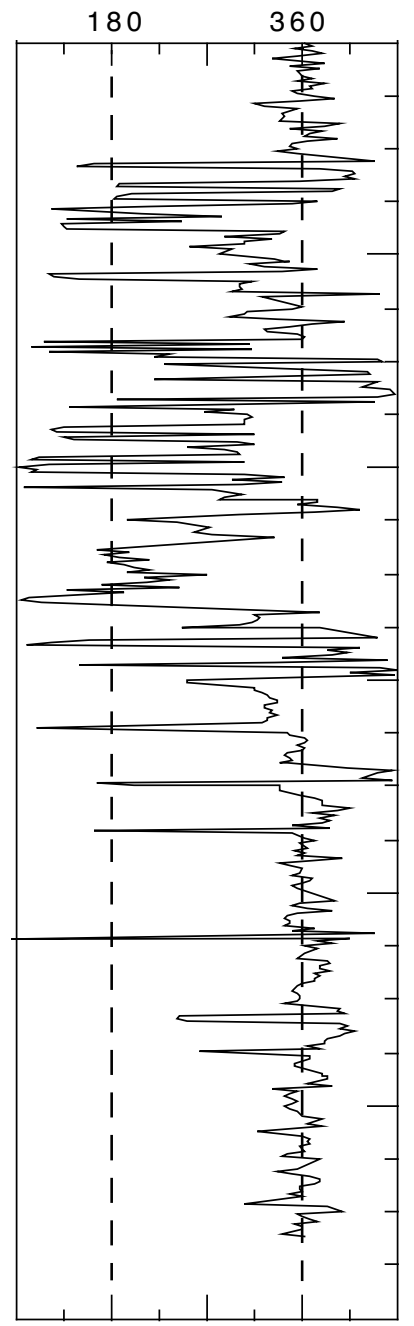


Figure F7. Hole U1324B (A) natural remanent magnetization (NRM) intensity for $0 \mathrm{mT}$ (light gray) and $30 \mathrm{mT}$ (dark gray) AF demagnetization steps, ChRM (B) inclination and (C) declination.

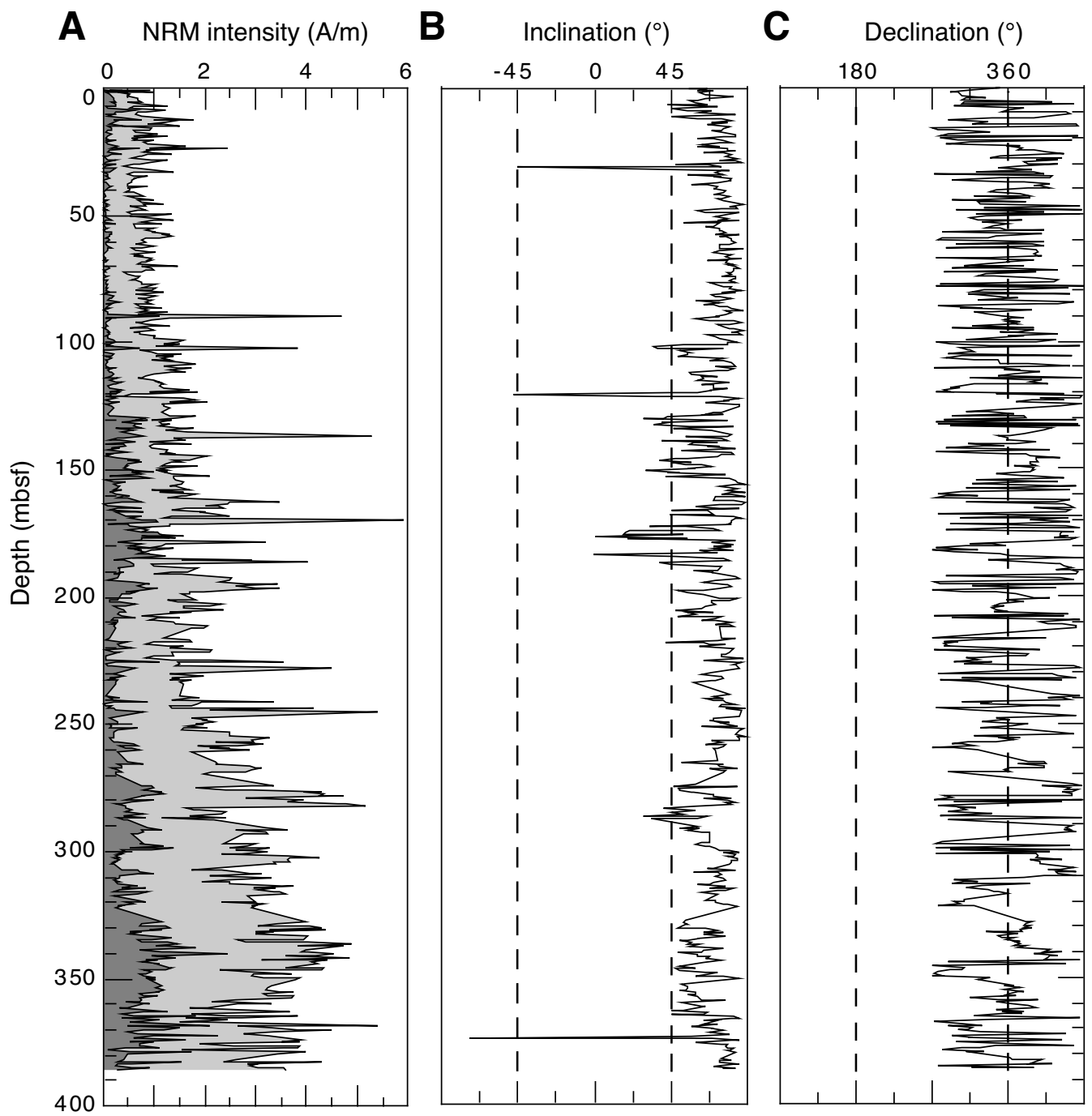


Figure F8. SEM micrographs of (A, B) Samples 308-U1319A-2H-CC (14.4 mbsf) and (C, D) 308-U1319A-3H-CC (23.8 mbsf). See "SEM analyses of the magnetic mineral assemblage (Hole U1319A)" for description of numbered particles.
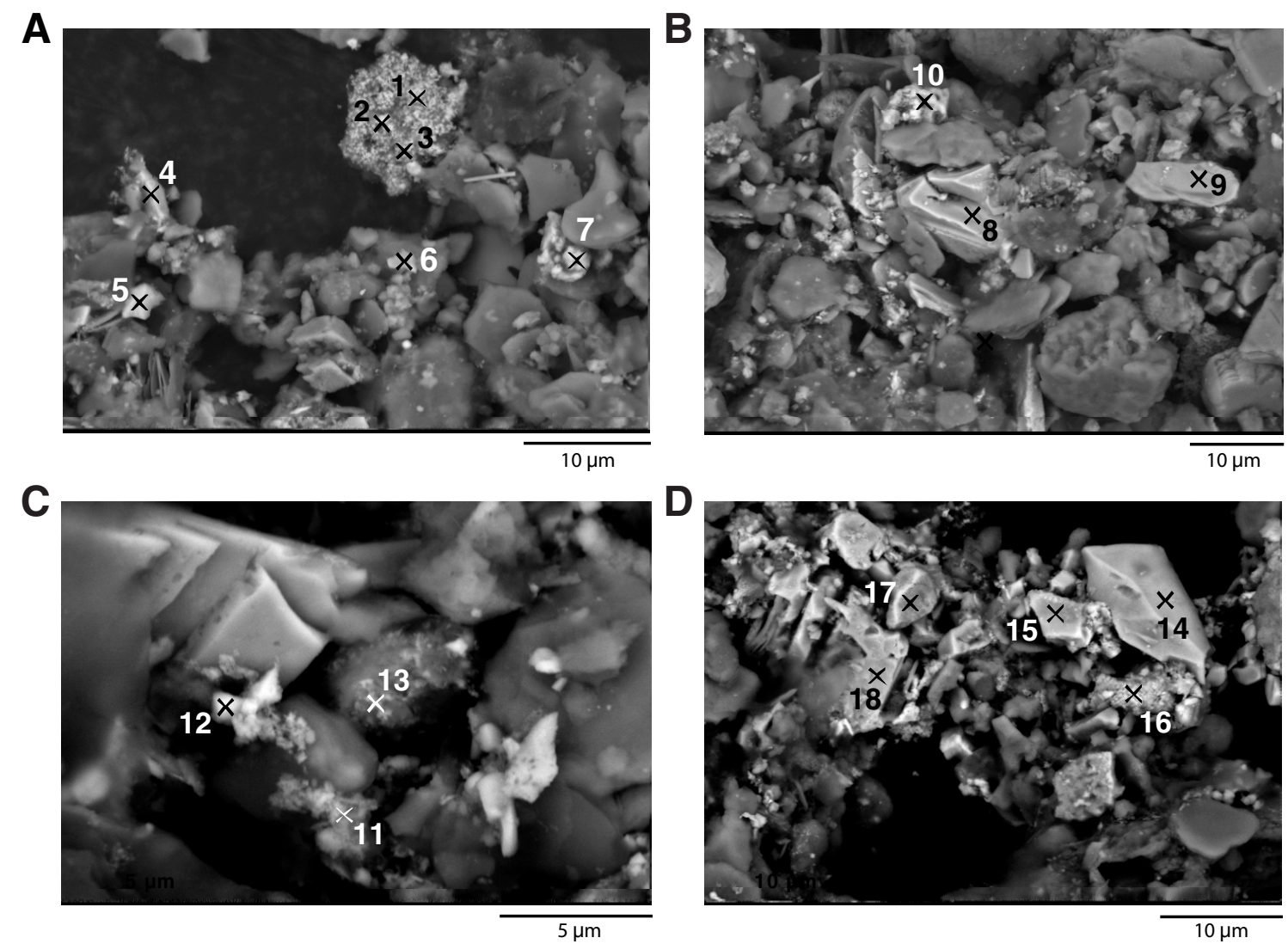
Table T1. Total inclination and declination values per site. (See table notes.)

\begin{tabular}{lccc}
\hline Hole & $N_{\text {tot }}$ & $\begin{array}{c}\text { Total } \\
\text { inclination } \\
\left({ }^{\circ}\right)\end{array}$ & $\begin{array}{c}\text { Total } \\
\text { declination } \\
\left({ }^{\circ}\right)\end{array}$ \\
\hline 308- & & & \\
U1319A & 296 & 44.4 & $345.9(1.9)$ \\
U1320A & 353 & 48.8 & 1.0 \\
U1322B & 424 & 32.4 & 327.9 \\
U1324B & 648 & 68.5 & 0.2 \\
\hline
\end{tabular}

Notes: $N_{\text {tot }}=$ number of vertically oriented samples analyzed from each hole. Value in parentheses = mean declination value for Site U1319 calculated for the nondisturbed drill Cores 308-U1319-1H through $7 \mathrm{H}$; see text for further explanation. 
Table T2. Inclination and declination values for each $10 \mathrm{~m}$ drill core, Expedition 308. (See table note.)

\begin{tabular}{|c|c|c|c|}
\hline Core & $N$ & $\begin{array}{c}\text { Inclination } \\
\left({ }^{\circ}\right)\end{array}$ & $\begin{array}{c}\text { Declination } \\
\left({ }^{\circ}\right)\end{array}$ \\
\hline \multicolumn{4}{|c|}{ 308-U1319A- } \\
\hline $1 \mathrm{H}$ & 9 & 55.56 & -87.64 \\
\hline $2 \mathrm{H}$ & 19 & 47.10 & 105.19 \\
\hline $3 \mathrm{H}$ & 20 & 51.96 & -24.87 \\
\hline $4 \mathrm{H}$ & 20 & 49.05 & -64.15 \\
\hline $5 \mathrm{H}$ & 20 & 51.02 & -114.61 \\
\hline $6 \mathrm{H}$ & 21 & 44.61 & -76.27 \\
\hline $7 \mathrm{H}$ & 18 & 43.09 & -10.97 \\
\hline $8 \mathrm{H}$ & 20 & 28.19 & -1.53 \\
\hline $9 \mathrm{H}$ & 17 & 23.98 & 5.15 \\
\hline $10 \mathrm{H}$ & 18 & 36.36 & -65.21 \\
\hline $11 \mathrm{H}$ & 19 & 36.13 & -15.81 \\
\hline $12 \mathrm{H}$ & 15 & 27.88 & -78.23 \\
\hline $13 \mathrm{H}$ & 15 & 36.89 & -64.94 \\
\hline $14 X$ & 10 & 64.69 & 59.75 \\
\hline $15 \mathrm{X}$ & 15 & 51.84 & 29.63 \\
\hline $16 \mathrm{X}$ & 13 & 34.03 & 31.19 \\
\hline $17 X$ & 14 & 53.93 & 39.13 \\
\hline $18 \mathrm{X}$ & 13 & 62.29 & 80.08 \\
\hline \multicolumn{4}{|c|}{ 308-U1320A- } \\
\hline $1 \mathrm{H}$ & 9 & 53.32 & 0.00 \\
\hline $2 \mathrm{H}$ & 19 & 36.77 & 0.33 \\
\hline $3 \mathrm{H}$ & 19 & 36.50 & 23.77 \\
\hline $4 \mathrm{H}$ & 18 & 29.04 & 0.00 \\
\hline $5 \mathrm{H}$ & 12 & 32.82 & 0.00 \\
\hline $15 \mathrm{X}$ & 18 & 52.22 & 0.00 \\
\hline $16 \mathrm{X}$ & 17 & 56.03 & 0.00 \\
\hline $17 X$ & 19 & 55.25 & 0.00 \\
\hline $18 \mathrm{X}$ & 18 & 56.36 & 0.00 \\
\hline $19 x$ & 18 & 49.20 & -2.34 \\
\hline $22 x$ & 18 & 56.06 & 0.00 \\
\hline $23 x$ & 17 & 54.09 & 0.00 \\
\hline $24 X$ & 17 & 46.26 & 0.00 \\
\hline $25 X$ & 17 & 52.13 & 0.00 \\
\hline $26 x$ & 17 & 47.35 & 0.00 \\
\hline $27 X$ & 18 & 45.82 & 0.00 \\
\hline $28 \mathrm{X}$ & 18 & 45.58 & 0.00 \\
\hline $29 x$ & 16 & 44.31 & 0.00 \\
\hline $30 x$ & 17 & 53.63 & 0.00 \\
\hline $31 x$ & 17 & 53.41 & 0.00 \\
\hline $32 x$ & 14 & 67.79 & 0.00 \\
\hline \multicolumn{4}{|c|}{ 308-U1322B- } \\
\hline $1 \mathrm{H}$ & 7 & 44.97 & 0.25 \\
\hline $2 \mathrm{H}$ & 19 & 52.88 & 0.00 \\
\hline $3 \mathrm{H}$ & 16 & 43.56 & 0.00 \\
\hline $4 \mathrm{H}$ & 19 & 40.57 & -56.84 \\
\hline $5 \mathrm{H}$ & 18 & 25.04 & -120.00 \\
\hline $6 \mathrm{H}$ & 17 & 46.03 & -63.53 \\
\hline $7 \mathrm{H}$ & 19 & 29.51 & -56.84 \\
\hline $8 \mathrm{H}$ & 15 & 5.61 & 0.00 \\
\hline $9 \mathrm{H}$ & 19 & 14.36 & -113.68 \\
\hline $10 \mathrm{H}$ & 20 & 6.70 & -126.00 \\
\hline $11 \mathrm{H}$ & 15 & 35.72 & -48.00 \\
\hline $12 \mathrm{H}$ & 18 & 49.32 & -160.00 \\
\hline $13 \mathrm{H}$ & 11 & 45.21 & -98.18 \\
\hline $14 \mathrm{H}$ & 16 & 5.14 & -22.50 \\
\hline $15 \mathrm{H}$ & 17 & 27.97 & -42.35 \\
\hline $16 \mathrm{H}$ & 15 & 18.36 & -24.00 \\
\hline $17 \mathrm{H}$ & 15 & 8.84 & 0.00 \\
\hline $18 \mathrm{H}$ & 14 & 31.47 & 0.00 \\
\hline $19 \mathrm{H}$ & 16 & 32.66 & 0.00 \\
\hline
\end{tabular}

\begin{tabular}{|c|c|c|c|}
\hline Core & $N$ & $\begin{array}{c}\text { Inclination } \\
\left({ }^{\circ}\right)\end{array}$ & $\begin{array}{c}\text { Declination } \\
\left({ }^{\circ}\right)\end{array}$ \\
\hline $20 \mathrm{H}$ & 14 & 31.29 & 0.00 \\
\hline $21 \mathrm{H}$ & 14 & 35.17 & 0.00 \\
\hline $22 \mathrm{H}$ & 13 & 26.64 & 0.00 \\
\hline $23 \mathrm{H}$ & 18 & 28.79 & 0.00 \\
\hline $24 \mathrm{H}$ & 4 & 38.00 & 0.00 \\
\hline $25 \mathrm{H}$ & 16 & 39.24 & 0.00 \\
\hline $26 \mathrm{H}$ & 5 & 58.66 & 0.00 \\
\hline $27 \mathrm{H}$ & 10 & 42.32 & 0.00 \\
\hline $28 \mathrm{H}$ & 12 & 24.38 & 0.00 \\
\hline $29 \mathrm{H}$ & 12 & 50.54 & 0.00 \\
\hline \multicolumn{4}{|c|}{ 308-U1324B- } \\
\hline $1 \mathrm{H}$ & 6 & 63.36 & -41.13 \\
\hline $2 \mathrm{H}$ & 18 & 64.20 & -0.62 \\
\hline $3 \mathrm{H}$ & 19 & 74.01 & -24.41 \\
\hline $4 \mathrm{H}$ & 18 & 67.96 & 25.82 \\
\hline $5 \mathrm{H}$ & 18 & 72.60 & 9.35 \\
\hline $6 \mathrm{H}$ & 18 & 76.68 & 5.65 \\
\hline $7 \mathrm{H}$ & 17 & 74.59 & -17.84 \\
\hline $8 \mathrm{H}$ & 18 & 77.75 & 5.13 \\
\hline $9 \mathrm{H}$ & 19 & 79.94 & 1.34 \\
\hline $10 \mathrm{H}$ & 18 & 75.48 & -7.22 \\
\hline $11 \mathrm{H}$ & 18 & 76.91 & 2.82 \\
\hline $12 \mathrm{H}$ & 18 & 62.94 & -25.43 \\
\hline $13 \mathrm{H}$ & 17 & 70.54 & 10.19 \\
\hline $14 \mathrm{H}$ & 16 & 63.32 & 15.25 \\
\hline $15 \mathrm{H}$ & 15 & 56.57 & -3.90 \\
\hline $16 \mathrm{H}$ & 16 & 69.02 & -7.27 \\
\hline $17 \mathrm{H}$ & 17 & 53.17 & 25.49 \\
\hline $18 \mathrm{H}$ & 16 & 81.82 & -10.45 \\
\hline $19 \mathrm{H}$ & 17 & 72.93 & 32.05 \\
\hline $20 \mathrm{H}$ & 15 & 49.07 & 42.04 \\
\hline $21 \mathrm{H}$ & 14 & 66.56 & -23.77 \\
\hline $22 \mathrm{H}$ & 10 & 67.03 & 53.92 \\
\hline $23 \mathrm{H}$ & 11 & 68.92 & -9.85 \\
\hline $24 \mathrm{H}$ & 13 & 67.29 & 7.50 \\
\hline $25 \mathrm{H}$ & 10 & 71.58 & 38.38 \\
\hline $26 \mathrm{H}$ & 11 & 71.44 & -47.85 \\
\hline $27 \mathrm{H}$ & 11 & 80.28 & -4.50 \\
\hline $28 \mathrm{H}$ & 8 & 69.55 & 0.34 \\
\hline $29 \mathrm{H}$ & 13 & 76.94 & 11.68 \\
\hline $30 \mathrm{H}$ & 16 & 79.59 & 5.46 \\
\hline $31 \mathrm{H}$ & 8 & 72.08 & -51.81 \\
\hline $32 \mathrm{H}$ & 10 & 72.35 & 13.60 \\
\hline $33 \mathrm{H}$ & 17 & 66.39 & 32.65 \\
\hline $34 \mathrm{H}$ & 10 & 48.63 & -42.17 \\
\hline $35 \mathrm{H}$ & 6 & 59.73 & 72.40 \\
\hline $36 \mathrm{H}$ & 18 & 75.64 & -2.85 \\
\hline $37 \mathrm{H}$ & 9 & 71.81 & 57.90 \\
\hline $38 \mathrm{H}$ & 12 & 72.18 & -31.27 \\
\hline $39 \mathrm{H}$ & 6 & 74.37 & -57.88 \\
\hline $40 \mathrm{H}$ & 11 & 59.92 & 16.36 \\
\hline $41 \mathrm{H}$ & 10 & 60.92 & 5.83 \\
\hline $42 \mathrm{H}$ & 11 & 63.62 & 42.51 \\
\hline $43 \mathrm{H}$ & 12 & 63.07 & -68.89 \\
\hline $44 X$ & 9 & 55.45 & 5.23 \\
\hline $45 X$ & 7 & 62.83 & 3.43 \\
\hline $46 \mathrm{H}$ & 10 & 65.85 & 1.16 \\
\hline $47 \mathrm{H}$ & 9 & 68.17 & -37.18 \\
\hline $48 \mathrm{H}$ & 13 & 65.71 & -23.62 \\
\hline
\end{tabular}

Note: $N=$ number of vertically oriented samples analyzed per drill core. 
Table T3. Semiquantitative EDS analyses. (See table notes.)

\begin{tabular}{|c|c|c|c|c|c|c|c|c|c|}
\hline $\begin{array}{l}\text { Depth } \\
\text { (mbsf) }\end{array}$ & Particle & $\underset{(\text { at\%) }}{S}$ & $\begin{array}{c}\mathrm{Ti} \\
\text { (at\%) }\end{array}$ & $\begin{array}{c}\mathrm{Fe} \\
(\mathrm{at} \%)\end{array}$ & $\begin{array}{l}\mathrm{Fe} / \mathrm{S} \\
\text { ratio }\end{array}$ & $\begin{array}{l}\mathrm{Fe} / \mathrm{Ti} \\
\text { ratio }\end{array}$ & Identified mineral phase(s) & $\begin{array}{c}\mathrm{TH} \\
\text { calculated } \\
2 \mathrm{Ti} /(\mathrm{Ti}+\mathrm{Fe})\end{array}$ & $\begin{array}{c}\text { TM } \\
\text { calculated } \\
3 \mathrm{Ti} /(\mathrm{Ti}+\mathrm{Fe})\end{array}$ \\
\hline 14.35 & 1 & 10.47 & 0.00 & 9.14 & 0.87 & - & Greigite & - & - \\
\hline 14.35 & 2 & 6.91 & 0.00 & 6.27 & 0.91 & - & Greigite & - & - \\
\hline 14.35 & 3 & 8.15 & 0.00 & 6.82 & 0.84 & - & Greigite & - & - \\
\hline 14.35 & 4 & 0.00 & 1.50 & 6.03 & - & 4.02 & Titanomagnetite & - & TM60 \\
\hline 14.35 & 5 & 0.00 & 4.04 & 4.42 & - & 1.09 & Titanohematite & TH96 & - \\
\hline 14.35 & 6 & 0.00 & 6.57 & 5.47 & - & 0.83 & Pseudobrookite/rutile & - & - \\
\hline 14.35 & 7 & 0.00 & 0.00 & 9.14 & - & - & Magnetite & - & TMO \\
\hline 14.35 & 8 & 0.00 & 1.42 & 18.83 & - & 13.45 & Titanomagnetite & - & TM21 \\
\hline 14.35 & 9 & 0.00 & 8.95 & 14.70 & - & 1.64 & Titanohematite & TH76 & - \\
\hline 14.35 & 10 & 0.00 & 0.00 & 28.75 & - & - & Magnetite & - & TMO \\
\hline 23.84 & 11 & 1.89 & 0.47 & 9.90 & 5.24 & 21.06 & Mixed phase (titanomagnetite + sulfide) & - & TM14 \\
\hline 23.84 & 12 & 5.67 & 0.00 & 3.43 & 0.60 & - & Pyrite & - & - \\
\hline 23.84 & 13 & 15.44 & 0.49 & 10.24 & 0.66 & 20.90 & Mixed phase (pyrite + titanomagnetite) & - & TM14 \\
\hline 23.84 & 14 & 0.00 & 4.84 & 8.01 & - & 1.65 & Titanohematite & TH75 & - \\
\hline 23.84 & 15 & 0.00 & 0.00 & 15.98 & - & - & Magnetite & - & TM0 \\
\hline 23.84 & 16 & 1.96 & 0.65 & 11.87 & 6.06 & 18.26 & Mixed phase (titanomagnetite + sulfide) & - & TM16 \\
\hline 23.84 & 17 & 0.00 & 3.05 & 19.81 & - & 6.50 & Titanomagnetite & - & TM40 \\
\hline 23.84 & 18 & 0.00 & 0.00 & 20.14 & - & - & Magnetite & - & TM0 \\
\hline 23.84 & $19^{*}$ & 0.00 & 1.94 & 13.25 & - & 6.83 & Titanomagnetite & - & TM38 \\
\hline 23.84 & $20^{*}$ & 0.00 & 0.00 & 16.86 & - & - & Magnetite & - & TM0 \\
\hline 23.84 & 21 * & 4.80 & 0.00 & 3.74 & 0.78 & - & Greigite & - & - \\
\hline 23.84 & $22^{*}$ & 5.37 & 0.00 & 4.04 & 0.75 & - & Greigite & - & - \\
\hline 23.84 & $23^{*}$ & 5.77 & 0.00 & 4.61 & 0.80 & - & Greigite & - & - \\
\hline
\end{tabular}

Notes: Results give the elemental composition of the individual particles from the Site U1319 magnetic extracts of 14.4 and $23.8 \mathrm{mbsf}$. Particle numbers refer to numbers given in Figure F8. ${ }^{*}=$ particle not shown in Figure F8. Titanohematite (TH) and titanomagnetite (TM) compositions calculated according to the stoichiometric formulas $\mathrm{Fe}_{2-\mathrm{y}} \mathrm{Ti}_{\mathrm{y}} \mathrm{O}_{3}$ and $\mathrm{Fe}_{3-\mathrm{x}} \mathrm{Ti}_{\mathrm{x}} \mathrm{O}_{4}$, respectively. $-=$ not applicable. 